\title{
PENGARUH PENGUNGKAPAN OTHER COMPREHENSIVE INCOME TERHADAP ASIMETRI INFORMASI YANG DIMODERASI OLEH KUALITAS AUDIT PADA PERUSAHAAN SEKTOR KEUANGAN YANG TERDAFTAR DI BEI TAHUN 2012-2016
}

\author{
Nini Sumarni \\ Institut Agama Islam Negeri Bukittingi \\ nnsumarni@gmail.com
}

\begin{abstract}
The changes in accounting standards in Indonesia that use international-based standards are the focus of important attention for company management, because company management has to report other comprehensive income. Other comprehensive income components contain high assumptions, estimations, and judgments from the management, therefore high audit quality is being able to support a decrease in information asymmetry. This study aims to analyze the effect of disclosure of other comprehensive income on information asymmetry in financial sector companies listed on the Indonesia Stock Exchange in 2012-2016. This type of research is descriptive verification. The dependent variable in this study is information asymmetry. The independent variable in this study uses the OCI ratio, while the audit quality as a moderator variable uses a dummy variable, where the big four KAP is given value of 1 and the non-big four KAP is given a value of 0 . The control variable is the size of the company measured by natural asset logarithms. This study uses secondary data, namely financial data sourced from the website. The results of the study through the F test is a significant value of $0.003(<0.005)$.
\end{abstract}

Keywords: Comprehensive Income, Information Asymmetry, Audit Quality.

\begin{abstract}
ABSTRAK
Perubahan standar akuntansi di Indonesia yang menggunakan standar berbasis internasional menjadi fokus perhatian penting bagi manajemen perusahaan, karena manajemen perusahaan harus melaporkan other comprehensive income. Komponen other comprehensive income mengandung asumsi, estimasi, dan judgment yang tinggi dari manajemen, oleh karenanya kualitas audit yang tinggi dapat mendukung penurunan asimetri informasi. Penelitian ini bertujuan untuk menganalisis pengaruh pengungkapan other comprehensive income terhadap asimetri informasi pada perusahaan sektor keuangan yang terdaftar di Bursa Efek Indonesia pada tahun 2012-2016. Jenis penelitian ini adalah deskriptif verifikatif. Variabel dependen pada penelitian ini adalah asimetri informasi . Variabel independen pada penelitian ini menggunakan rasio OCI, sedangkan kualitas audit sebagai variabel moderator menggunakan variabel dummy, dimana KAP big four diberi bobot 1 dan KAP non-big four diberi bobot 0 . Variabel kontrol yaitu ukuran perusahaan yang diukur dengan logaritma natural asset. Penelitian ini menggunakan data sekunder yaitu data keuangan yang bersumber dari website. Hasil penelitian melalui uji F dengan nilai signifikan sebesar 0.003(<0.005).
\end{abstract}

Kata kunci: Penghasilan Komprehensif, Asimetri Informasi, Kualitas Audit 


\section{Pendahuluan}

Perusahaan sebagai penyedia informasi untuk investor, wajib mengungkapkan laporan keuangan yang lengkap dan juga transparan, sehingga investor bisa mendapatkan keputusan yang tepat sasaran dan sesuai. Pemegang saham sebagai stakeholder membutuhkan penungkapan laporan keuangan yang transparan dan akuntabel, sedangkan pihak manajemen perusahaan cenderung untuk tidak mengungkapkan informasi keuangan yang rahasia dan juga penting. Kondisi ketika terjadi kepentingan investor dan manajemen yang berbeda akan menimbulkan asimetri informasi. Asimetri informasi disebut sebagai sebuah keadaan yang terjadi pada saat informasi yang dipunyai oleh pihak manajerial perusahaan dan pihak investor berbeda.

Asimetri informasi yang timbul antara manajerial dengan investor (principal) akan memunculkan kesempatan untuk manajer bisa bertindak oportunis, dengan cara mencari keuntungan pribadi (Ujiyanto, 2007). Supaya asimetri informasi ini bisa berkurang maka perusahaan bisa melakukan dengan menyajikan laporan keuangan perusahaan yang transparan dan akuntabel pada pemegang saham. Asimetri informasi dapat dipengaruhi oleh ukuran perusahaan. Untuk perusahaan yang dalam skala besar, dalam pengungkapan laporan keuangannya akan lebih hati-hati dan akuntabel, terjadi karena perusahaan tersebut telah menjadi perusahaan terbuka dan listing di IDX, sehingga laporan keuangan mereka akan menjadi perhatian oleh masyarakat. Hal ini akan berakibat pada laporan keuangan yang lebih akuntabel dan juga informatif (Sumarni,2016).

Deanglo (1981), menyatakan bahwa kualitas audit adalah kemampuan auditor untuk dapat menilai laporan keuangan dengan baik, dengan cara menjadikan tolak ukur dari kualitas KAP. Untuk mengukur kualitas audit dengan cara ukuran KAP. KAP yang tergolong big four mempunyai kualitas audit yang lebih baik dan lengkap jika 
dibandingkan dengan KAP non big four. Akbar (2015) menyatakan bahwa standar akuntansi yang terbaik bisa memberikan informasi yang berkualitas tentang kondisi laporan keuangan perusahaan. Standar akuntansi adalah panduan yang dihasilkan oleh suatu badan pembuat standar yang akan digunakan dalam menyusun laporan keuangan dan juga akan digunakan dalam menganalisa laporan keuangan.

Standar Akuntansi tentang pengungkapan PSAK 1 mengenai penyajian pada laporan keuangan, PSAK 1 (Revisi 2009) membahas tentang penyajian di laporan keuangan, dimana perusahaan wajib menyebutkan pos other comprehensive income (OCI) dalam laporan rugi laba dan catatan atas laporan keuangan pada sebuah periode akuntansi. Penyajian OCI pada laporan keuangan adalah pengungkapan wajib yang telah diatur oleh regulator akuntansi untuk perusahaan yang memiliki akun-akun OCI (Sumarni, 2016). Pengungkapan OCI yang merupakan indikator dalam kelengkapan pelaporan keuangan diharapkan bisa menurunkan asimetri. Terbukti pada penelitian Greenstein dan Sami (1994) yang membuktikan bahwa kewajiban pengungkapan informasi akuntansi oleh SEC kepada perusahaan yang terdaftar di bursa Amerika Serikat berpengaruh pada asimetri informasi dan juga berakibat pada menurunnya nilai bidaskspread.

\section{RUMUSAN MASALAH}

Rumusan masalah pada penelitian ini adalah "apakah pengungkapan other comprehensive income berpengaruh terhadap asimetri informasi yang dimoderasi oleh kualitas audit pada perusahaan sektor keuangan yang terdaftar di BEI tahun 2012-2016?

\section{TUJUAN PENELITIAN}

Tujuan penelitian adalah untuk mengetahui pengaruh pengungkapan other comprehensive income (OCI) terhadap asimetri informasi yang dimoderasi oleh kualitas 
audit pada perusahaan sektor keuangan yang terdaftar di BEI tahun 2012-2016.

\section{Landasan Teori}

\section{Agency Theory}

Teori agency adalah model hubungan antara dua orang atau lebih (pihak), yaitu antaraagent dan principal. Principal adalah pemegang saham dan akan memberikan tanggung kepada agent atau manajerial untuk pengambilan keputusan dan juga melaksanakan tugas berdasarkan kesepakatan antara manajerial dan pemegang saham.Scott (2009), terjadi banyak perjanjian dalam perusahaan, seperti perjanjian antara perusahaan dengan manajer, perjanjian antara perusahaaan dengan pihak investor. Investor dan manajer masing-masingnya ingin memaksimalkan kemampuan dengan informasi informasi tentang perusahaan yang mereka ketahui. Pada realitanya, manajerial mempunyai info yang lebih dibandingkan dengan investor, sehingaa terjadi asimetri informasi. Manajer yang bergerak dalam operasional perusahaan memiliki info yang akan digunakan untuk keuntungan pribadi. Pihak investor sebagai pihak luar perusahaan akan merasakan kesulitan untuk mengawasi segala kegiatan dalam perusahaan yang dilaksanakan oleh manajemen, karena mereka tidak memiliki akses penuh seperti manajemen terhadap perusahaan. Hal ini menimbulkan adanya keputusan-keputusan yang dilakukan oleh manajemen yang tidak diketahui oleh investor.

\section{Asimetri Informasi}

Pada dunia transaksi bisnis, ada kondisi dimana antara pihak yang bertransaksi, ada yang memiliki informasi yang lebih dibanding dengan yang lainnya. Kondisi ini yang menjadikan asimetri informasi. Pada perusahaan, antara pihak manajerial dan investor, jika ada yang memiliki informasi terkait keadaan dan kegiatan pada perusahaan yang lebih banyak dibandingkan dengan pihak lainnya. Investor sebagai orang luar 
perusahaan mempunyai kondisi yang terbatas untuk bisa berpedoman pada laporan keuangan yang dikeluarkan oleh peursahaan dan output dari manajemen. Adanya beberapa informasi yang ditutup tutupi oleh pihak manajemen perusahaan bisa menyebabkan investor dan juga pihak eksternal salah dalam pengambilan keputusan yang terkait dengan perusahaan.

\section{Kualitas Audit}

De Angelo pada tahun 1981 telah menyebutkan kualitas audit merupakan kesempatan seorang auditor untuk melacakadanya ketidaktepatan atau ketidaksesuaian sistem akuntansi audit kepada standar yang berlaku umum. Kebebasan auditor dalam proses audit akan memberikan kesempatan yang lebih luas untuk mendeteksi kesalahan kesalahan. Untuk mendeteksi kesalahan atau pelanggaran, terdapat dua hal utama, yaitu a. auditor memiliki kesempatan untuk mendeteksi kesalahan, dan b. keinginandari auditor supaya bisa mendeteksi kesalahan dan pelangaran. Untuk bisa mendeteksi kesalahan-kesalahan,auditor harus memiliki kemampuan, keinginan dan indepensi auditor. Sehingga kemampuan dan independensi adalah faktor utama untuk mengukur kualitas audit.

\section{Ukuran Perusahaan}

Ukuran perusahaan adalah determinan dari struktur keuangan dalam setiap penelitian untuk alasan yang berbeda. Pertama ukuran perusahaan bisa menjadi dasar penentuan apakah perusahaan bisa memperoleh dana invesatsi dari pasar modal. Jika perusahaan berukuran kecil maka mereka hanya memiliki sedikit kesempatan untuk memasuki pasar modal (Sawir, 2004). Kedua ukuran perusahaan adalah faktor penentu dalam kondisi tawar menawar ekonomi. Jika perusahaan adalah sebuah perusahaan besar maka mereka bisa mengakses pendanaan dari banyak sumber seperti hutang, 
saham dan obligasi, tergantung piihan mana yang lebih menguntungkan. Semakin besar pendanaannya maka besar juga kontrak yang dibuat sesuai dengan keinginan kedua belah pihak. Ketiga, perusahaan dengan skala besar memiliki kesempatan menndapatkan laba yang semakin besar, akibat adanya pengaruh skala biaya dan retur.

Machfoed (1994), ukuran perusahaan bisa diukur dengan caramelihat total penjualan, jumlah total aset, dan jumlah sdm. Struktur modal dari sebuah perusahaan dipengaruhi oleh ukuran perusahaan. Sehingga perusahaan yang membutuhkan dana besar untuk modal pastinya akan meningkatkan cara untuk meningkatkan laba..

\section{Other Comprehensive Income}

Berdasarkan revisi IFRS, laporan keuangan salah satunya adalah laporan rugi laba, yaitu laporan yang memuat tentang kinerja dari perusahaan, terdiri atas pendapatan, beban dan laba atau rugi yang didapat dari selisih pendapatan dengan beban. Pada laporan laba rugi juga terdapat informasi mengenai keuntungan yang diperoleh perusahaan dan juga yang akan diterima oleh pemegang saham. Setelah adanya adopsi IFRS, laporan laba rugi juga menyajikan laba atau rugi perusahaan yang diperoleh dari kegiatanlainnya.

\section{Desain Penelitian}

Penelitian ini adalah studi empiris yang bersifat deskriptif verifikatif dengan pendekatan kuantitatif yang bertujuan untuk menganalisis variabel secarakeseluruhan. Pada penelitian ini, peneliti melakukan pengujian mengenai pengaruh pengungkapan other comprehensive incometerhadap asimetri informasi yang di moderasi oleh kualitas audit untuk perusahaan berukuran besar dan kecil. Penelitian ini mengambil data LK pada perusahaan sektor keuangan yang ada di BEI.Perusahaan sektor Keuangan pada tahun 2012 -2016 yang ada di BEI. Menggunakan data panel, yang terdiri dari dari banyak 
perusahan dan beberapa tahun. Data sekunder yang diambil dari website perusahaan dan juga dari LK di BEI.

Statistikdeskriptifuntuk penelitianini yaitumendeskripsikan variabel keuangan yang ada dalam LK perusahaan tahun 2012-2016. Alat analisis yang digunakan untuk mendeskripsikan variabel penelitian ini adalah nilai rata-rata, nilai maksimal, nilai minimal dan standardeviasi.

\section{Uji Asumsi Klasik}

Rosita (2012), menyatakan pengujian asumsi klasik bertujuan untuk memastikan bahwa persamaan regresiyangdidapatkan memiliki ketepatan dalam estimasi, tidak bersifat bias dan konsisten. Adapun pengujian asumsi klasik yang dilakukan adalah sebagai berikut:

a) UjiNormalitas

Uji normalitas digunakan untuk menguji apakah model regresi seluruh variabel yang ada mempunyai distribusi data yang normal atau mendekati normal.

b) UjiMultikolinieritas

Uji multikolonieritas dilakukan untuk menguji apakah pada sebuah model regresi ditemukan adanya korelasi antar variabel independent. Model regresi yang baik adalah model dengan semua variabel independent tidak berhubungan erat satu samalain karena jika terdapat hubungan linear antara.

c) UjiHeteroskedastisitas

Uji Heteroskedastisitas adalah untuk melihat apakah terdapat ketidaksamaan varians dari residual satu pengamatan ke pengamatan yang lain. Model regresi yang memenuhi persyaratan adalah dimana terdapat kesamaan varians dari residual 
pengamatan ke pengamatan yang lain tetap disebut homoskedastisitas.

Dalam SPSS metode yang sering digunakan untuk mendeteksi adanya heteroskedastisitas yaitu dengan melihat ada tidaknya pola tertentu pada scatterplot (Ghozali, 2013).Dasarpengambilan keputusan berkaitan dengan gambar tersebut adalah jika tidak terdapat pola yang jelas, yaitu jika titik- titiknya menyebar, maka diindikasikan tidak ada masalah hesteroskedastisitas.

d) UjiAutokolerasi

Uji auto korelasi bertujuan untuk menguji apakah dalam model regresi linear ada korelasi antara kesalahan pengganggu pada periode $(\mathrm{t})$ dengan kesalahan penganggu pada periode (t-1).Jika terjadi korelasi maka dinamakan ada masalah autokorelasi.Untuk mendeteksi ada atau tidaknya autokoroleasi dapat menggunakan cara dengan melihat durbin watson pada output yang akan dibandingkan dengan nilai tabel dengan menggunakan signifikansi 5\%, jumlah sampel (n) dan jumlah variabelindependent.

Dasar pengambilan keputusan (Ghozali,2011):

1. Jika d lebih kecil dari dL atau lebih besar dari $(4-\mathrm{dL})=$ terdapat autokorelasi

2. Jika d terletak antara dU dan (4-dU) = tidak adaautokorelasi

3. Jika d terletak antara $\mathrm{dL}$ dan $\mathrm{dU}$ atau diantara(4-dU) dan $(4-\mathrm{dl})=$ tidak ada kesimpulan

\section{Analisa Regresi Linear berganda}

Sugiyono (2013) pengujian hipotesis bertujuan untuk menguji data sampel sudah bisa mewakili populasi. Pada penelitian ini pengujian hipotesis yang digunakan adalah model regresi linear berganda.Pengujian ini dilakukan untuk mengetahui pengaruh suatu variabel independent terhadap variabel dependent. Model persamaannya adalah sebagai 
berikut:

Model persamaan

$S P R E A D=\boldsymbol{\alpha}+\boldsymbol{\beta}_{1} \mathbf{O C I}+\boldsymbol{\beta}_{2} \mathrm{KAP}+\boldsymbol{\beta}_{3} \mathbf{O C I} . \mathrm{KAP}+\boldsymbol{\beta}_{4} \mathbf{S I Z E}+\boldsymbol{\varepsilon}$

Keterangan:

$\begin{array}{ll}\text { Spread } & =\text { Asimetri Informasi } \\ \alpha & =\text { Konstanta } \\ \beta 1-\beta 4 & =\text { KoefisienRegresi } \\ \text { OCI } & =\text { Other Comprehensive Income } \\ \text { KAP } & =\text { Kualitas Audit } \\ \text { SIZE } & =\text { UkuranPerusahaan } \\ € & =\text { Error term, yaitu tingkat kesalahan penduga dalam penelitian }\end{array}$

\section{Uji Hipotesis}

Uji F dilakukan untuk menguji apakah model regresi yang digunakan fit. Dasar pengambilan keputusannya adalah dengan melihat nilai signifikan $\mathrm{F}$ pada output hasil regresi menggunakan SPSS dengan significance level $>0,05(\alpha=5 \%)$. Jika nilai signifikan lebih besar dari $\alpha$ maka hipotesis ditolak, yang berarti model regresi tidak fit.jika nilai signifikan lebih kecil dari $\alpha$ maka hipotesis diterima, yang berarti bahwa model regresifit.

\section{Koefisien Determinasi}

Koefisien determinasi $\left(\mathrm{R}^{2}\right)$ mengukur seberapa jauh kemampuan model dalam menerangkan variasi variabel dependen.Peneliti menggunakan nilai Adjusted $\mathrm{R}^{2}$ pada saat mengevaluasi mana model regresi terbaik .Tidak seperti $\mathrm{R}^{2}$, nilai Adjusted $\mathrm{R}^{2}$ dapat naik atau turun apabila satu variabel independen ditambahkan ke dalam model.Sehingga pada penelitian ini menggunakan adjusted $\mathrm{R}^{2}$ (Ghozali,2011).

\section{Pembahasan.}




\section{Asimetri informasi}

Variabel dependen pada penelitian ini yaitu asimetri informasi. Asimetri informasi adalah kondisi ketika terdapat perbedaan informasi yang dimiliki oleh pihak agent dan principal, perbedaan informasi yang dimiliki ini bisa menyebabkan perbedaan informasi yang diperoleh principal dan agent, sehingga berakibat pada kesalahan pengambilan keputusan. Pihak managemen sebagai agentakan lebih menutupi informasi yang bersifat penting dan rahasia sehingga tidak dilaporkan dalam laporan keuangan, karena akan memepengaruhi nilai perusahaan, disisi lain, principal sebagai pemegang saham membutuhkan informasi yang terkait dengan kinerja dan tanggung jawab manajemen dalam menjalankan perusahaan.

Asimetri informasibisadiukurdenganmetodebidaskspread.Untuk data bidaskspread didapatkan dari informasi harga perusahaan dari nilai bidaskspreadmasing-masing perusahaan.

\section{Other Comprehensive income}

Variabel independent pada penelitian ini adalah Other Comprehensive Income.Untuk mengukur nilai OCI dengan rasio yang membandingkan antara jumlah keuntungan/kerugian OCIyang diperoleh suatu perusahaan dengan jumlah all comprehensive income.Komponen OCI yang disajikan dalam laporan laba rugi komprehensif adalah sebagai berikut:

a. Perubahan dalam surplus revaluasi (PSAK 16: Asset Tetap \& PSAK 19: Asset Tidak Berwujud).

b. Keuntungan dan kerugian aktuaria atas program manfaat pasti yang diakui (PSAK 24: Imbalan Kerja).

c. Keuntungan dan kerugian yang timbul dari penjabaran laporan keuangan dari entitas asing (PSAK 11: Penjabaran Laporan Keuangan dalam Mata UangAsing). 
d. Keuntungan dan kerugian dari pengukuran kembali asset keuangan yang dikategorikan sebagai "available for sale" (PSAK 55: Instrumen Keuangan: Pengakuan dan Pengukuran).

e. Bagian efektif dari keuntungan dan kerugian instrument lindung nilai dalam rangka lindung nilai arus kas (PSAK 55: InstrumenKeuangan: Pengakuan danPengukuran).

2. Setiap keuntungan dan kerugian dari kelima pos-pos OCI diakui dalam laporan laba rugi komprehensif pada suatu periode tertentu disertai dengan pengungkapan dalam catatan atas laporan keuangan. Selain itu, perusahaan juga mengungkapkan jumlah pajak penghasilan terkait dengan pos-pos OCI, termasuk penyesuaian reklasifikasi, baik dalam laporan laba rugi komprehensif atau catatan atas laporan keuangan.

Dalam penelitian ini, jumlah sampel yang digunakan sebesar 34 perusahaan untuk periode 5 tahun, dengan jumlah observasi 170. Pengurangan sampel pada penelitian ini salah satu sebabnya adalah banyaknya perusahaan yang terdaftar di Bursa Efek Indonesia yang belum melakukan pengungkapan OCI. Beberapa perusahaan masih ada yang menggabungkan pendapatan lainnya yang berasal bukan dari kegiatan utama perusahaan ke dalam komponen laba rugi komprehensif, tanpa membuat komponen terpisah untuk OCI. Dari sampel yang digunakan pada penelitian ini, terdapat perusahaan yang mengalami kerugian untuk komponen OCI. Salah satu kerugian tersebut salah satunya dari transaksi selisih valuta asing. Sementara format single statement banyak dipilih perusahaan dalam melaporkan laba rugi comprehensive.

Komponenother comprehensive income pada perusahaan yang terdaftar di Bursa Efek Indonesia yang sering muncul yaitu PSAK 55 terkait keuntungan dan kerugian dari pengukuran kembali asset keuangan (instrument keuangan) yang tersedia untuk dijual. 
Selain itu komponen OCI yang sering muncul adalah PSAK 10 terkait keuntungan dan kerugian yang timbul dari penjabaran laporan keuangan dari entitas asing (selisihkurs).

\section{Analisis Data}

Analisis data pada penelitian ini bertujuan untuk merubah data yang telah diolah menjadi informasi, sehingga karakteristik atau sifat-sifat data tersebut dapat dengan mudah dipahami dan bermanfaat untuk menjawab masalah-masalah yang berkaitan dengan kegiatan penelitian. Analisis data yang digunakan pada penelitian ini menggunakan bantuan spps versi 17. Analisis data pada penelitian ini adalah sebagai berikut:

\section{Analisis Statistik Deskriptif}

Analisis statistik deskriptif dilakukan terhadap variabel dependent (asimetri informasi) variabel independent (pengungkapan other comprehensive income/OCI), variabel moderating (kualitas KAP) dan variabel control (ukuran perusahaan). Analisis ini digunakan untuk mengetahui deskripsi data yang diolah selama 5 tahun (2012-2016) dilihat dari nilai maksimum, nilai minimum, nilai rata-rata dan nilai standar deviasi. Hasil analisis deskriptif disajikan dalam tabel berikut:

\section{Tabel 4.3}

\section{Analisis Statistik Deskriptif}

\section{Descriptive Statistics}




\begin{tabular}{|c|c|c|c|c|c|}
\hline & Mini mum & Maxim um & Mean & $\begin{array}{l}\text { Std. } \\
\text { Deviation }\end{array}$ & $\mathrm{N}$ \\
\hline $\begin{array}{l}\text { BID ASK } \\
\text { SPREAD }\end{array}$ & 3.73 & 7.58 & .0696 & .12969 & 170 \\
\hline OCI & 4.89 & 8.54 & .2486 & .45710 & 170 \\
\hline KAP & .07 & 1.18 & .8988 & .30248 & 170 \\
\hline SIZE & 15.59 & 21.35 & 25.9198 & 3.12151 & 170 \\
\hline OCI*KA P & 4.36 & .75 & .2260 & .45073 & 170 \\
\hline
\end{tabular}

Tabel 4.3 menunjukkan nilai terendah (minimum), nilai tertinggi (maximum), rata rata (mean), dan deviasi standar (standard deviation) dari masing masing variabel. Penelitian ini menggunakan data sebanyak 170 yangterdiri dari 34 perusahaan yang terdaftar di Bursa Efek Indonesia untuk periode tahun2012-2016. Variabel bid ask spread memiliki nilai maksimum 7.58 , sedangkan nilai minimumnya 3.73 , dimana nilai mean sebesar 0.069 kemudian standar deviasinya sebesar 0.129. Kemudian untuk variabel OCI memiliki nilai maksimum 8.54 dan nilai minimum 4.89, sedangkan nilai mean sebesar 0.248 dan standar deviasi sebesar 0.457 . 
Untuk Variabel KAP memiliki nilai maksimum 1.18, sedangkan nilai minimumnya0.07, dimana nilai mean sebesar 0.898 kemudian standar deviasinya sebesar 0.302. Kemudian untuk variabel Ukuran Perusahaan memiliki nilai maksimum 21.35 dan nilai minimum 15.59, sedangkan nilai mean sebesar 25.918 dan standar deviasi sebesar 3.121 memiliki tingkat variabilitas yang rendah dan bersifat homogen. Pada variabel interaksi OCI*KAP, nilai maksimumnya adalah 4.75 dan nilai minimunya adalah 0.36 . Nilai rata-rata atau mean sebesar 0.226 dan standar deviasi adalah sebesar 0.450 .

\section{Uji AsumsiKlasik}

Uji asumsi klasik ini dilakukan untuk memenuhi persyaratan sebelum melakukan analisis regresi berganda agar hasil yang diperoleh menjadi lebih baik, linear dan tidak bias. Uji asumsi klasik yang telah dilakukan pada penelitian ini adalah sebagai berikut:

\section{UjiNormalitas}

Uji normalitas bertujuan untuk menguji model regresi variabel dependen dan variabel independen mempunyai distribusi normal atau tidak. Model regresi yang baik adalah memiliki distribusi data normal atau mendekati normal (Ghozali, 2001). Data yang baik adalah data yang mempunyai pola seperti distribusi normal (data tersebar secara normal). Distribusi data dikatakan tersebar secara normal apabila nilai sig $>\alpha 0,05$ dan dikatakan tidak normal apabila nilai sig $<\alpha$ 0,05. Berdasarkan pengolahan data untuk uji normalitas dilakukan dengan metode One Kolmogrov - Smirnov, diperoleh hasil bahwa semua data dalam penelitian ini adalah normal. Sebab nilai sig $>\alpha$ yaitu sebesar $(0,537>$ 0,05). Berikut adalah hasil pengujian data yang dilakukan dengan metode One Sample Kolmogrov - Smirnov, yang disajikan apda Tabel 4.4 di bawah ini : 
Tabel 4.4 Hasil UjiNormalitas

One-Sample Kolmogorov-Smirnov Test

\begin{tabular}{|ll|l|}
\hline & & Unstandardiz ed Residual \\
\hline $\mathrm{N}$ & Mean & 170 \\
Normal Parameters ${ }^{\mathrm{a}, \mathrm{b}}$ & Std. Deviation & 3.45402147 \\
& Absolute & .089 \\
Most Extreme Differences & Positive & .065 \\
& & .089 \\
& Negative & .399 \\
Kolmogorov-Smirnov Z & & \\
Asymp. Sig. (2-tailed) & & \\
\hline
\end{tabular}

a. Test distribution is Normal.

b. Calculated from data.

\section{Uji Multikolinearitas}

Pengujian terhadap multikolonieritas dilakukan untuk mengetahui apakah variabel independen tersebut tidak saling berkorelasi atau ada hubungan linear di antara variabel-variabel independen dalam model regresi yang digunakan. Salah satu cara yang digunakan untuk mendeteksi multikolonieritas adalah dengancara melihat nilai VIF (Varians Inflation Factor) dan tolerance dengan kriteria pengujian jika nilai VIF $<10$ 
dengan angka tolerance> 0.10, maka tidak terjadi multikolonieritas (Ghozali, 2013). Berdasarkan tabel 4.4 nilai tolerance dari semua variabel independen adalah besar dari 0.10 dan VIF kecil dari 10, maka dapat disimpulkan bahwa tidak terjadi masalah multikolonieritas pada model regresi, yang berarti bahwa semua variabel independen pada penelitian ini tidak ada hubungan yang erat satu sama lain. Model regresi yang baik adalah model dengan semua variabel independen tidak berhubungan erat satu sama lain.

Tabel 4.5

\section{Hasil Uji Multikolinearitas}

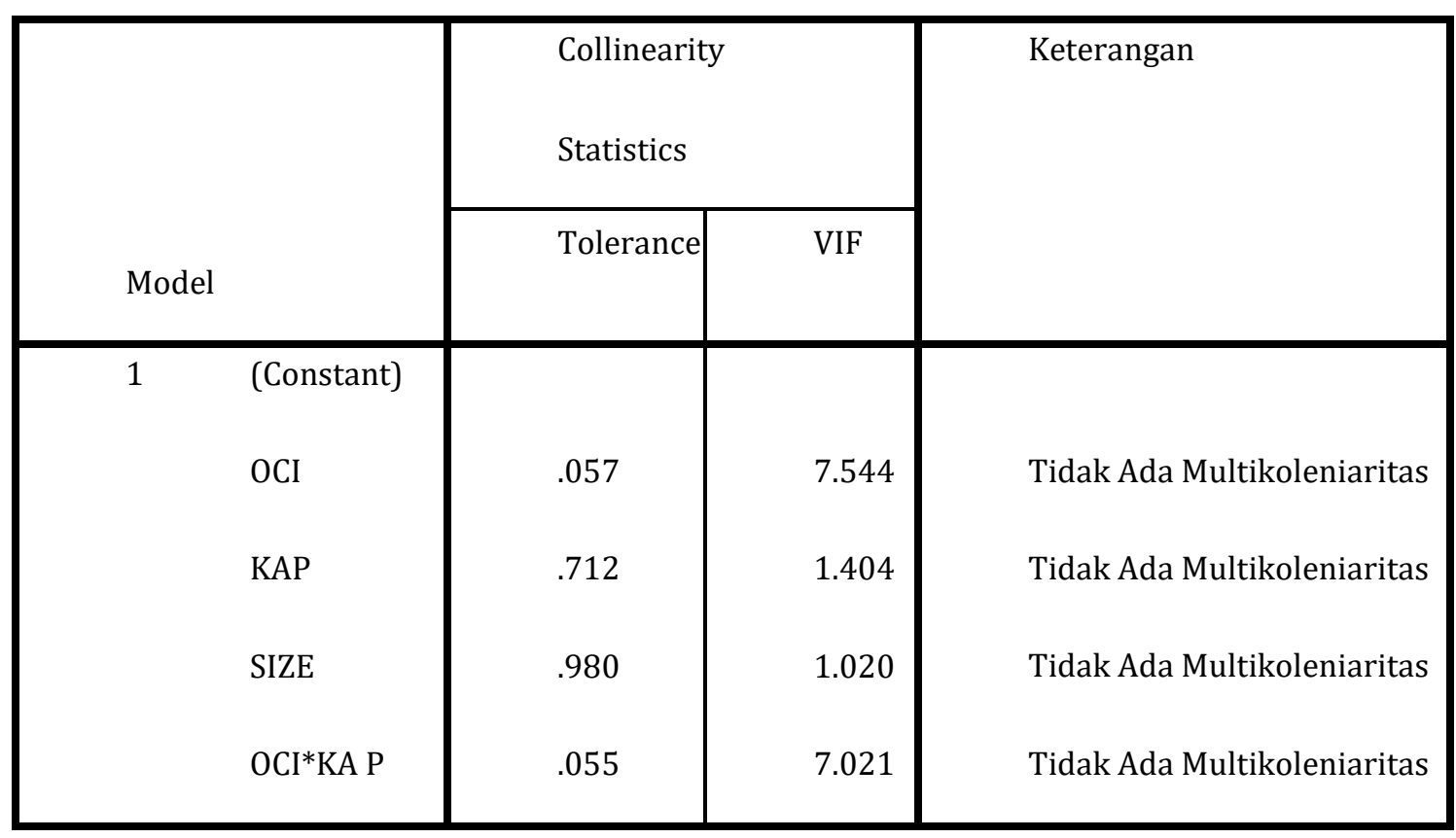

a. Dependent Variable: BID ASK SPREAD

Berdasarkan tabel 4.4 hasil uji multikolinearitas, nilai VIF variabel OCI sebesar 7.544, KAP sebesar 1.404, SIZE sebesar1.020, OCI*KAP 7.021, nilai VIF masing masing variabel dibawah 10 . Nilai tolerance masing masing variabel OCI adalah OCI sebesar 0.057, KAP sebesar 0.712, SIZE sebesar 0.980, dan OCI*KAP sebesar 0.055 masing masing variabel memiliki nilai tolerance di atas 0.10. Dari hasil ini dapat disimpulkan bahwa 
tidak terjadi masalah multikolinearitas pada model regresi, yang berarti bahwa semua variabel bebas (independent) pada penelitian ini tidak ada hubungan yang erat satu sama lain. Model regresi yang baik adalah model dengan semua variabel bebasnya tidak berhubungan erat satu sama lain.

\section{Uji Heteroskedastisitas}

Uji heteroskedastisitas bertujuan untuk menguji model regresi terjadi ketidaksamaan varian dari residual satu pengamatan ke pengamatan yang lain.Jika varian dari residual satu pengamatan ke pengamatan lain tetap, maka disebut homokedastisitas dan jika berbeda disebut heteroskedastisitas. Pengujian heteroskedastisitas dalam penelitian ini dilakukan dengan menggunakan scatterplot (Ghozali, 2013). Dasar pengambilan keputusan berkaitan dengan gambar tersebut adalah jika tidak terdapat pola yang jelas, yaitu jika titik-titiknya menyebar, maka diindikasikan tidak ada masalah hesteroskedastisitas.

\section{Gambar 4.1}

\section{Hasil Uji Heteroskedastisitas}

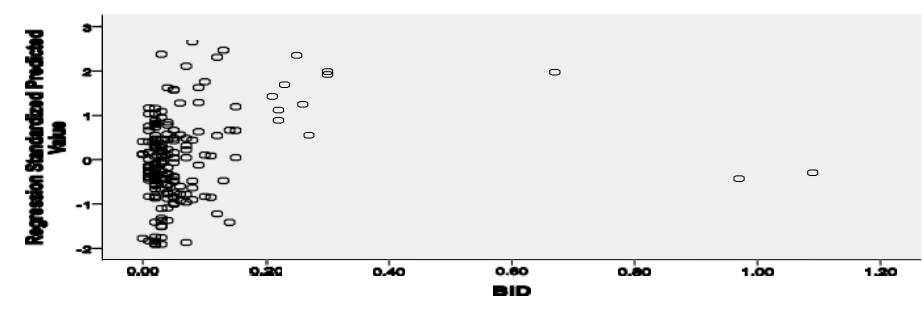

Berdasarkan gambar 4.3 di dapatkan hasil bahwa data dalam penelitian ini adalah tidak terjadi heterokedastisitas

\section{Uji Autokorelasi}


Untuk mendeteksi ada atau tidaknyaautokoroleasi dapat menggunakan cara dengan melihat durbin Watson pada output yang akan dibandingkan dengan nilai tabel dengan menggunakan signifikansi 5\%, jumlah sampel (n) dan jumlah variabel independent. Tidak ada autokorelasi positif satau negatif (tidak terdapat autokorelasi) (Ghozali,2011)

Tabel 4.5 Uji Autokorelasi

Model Summaryb

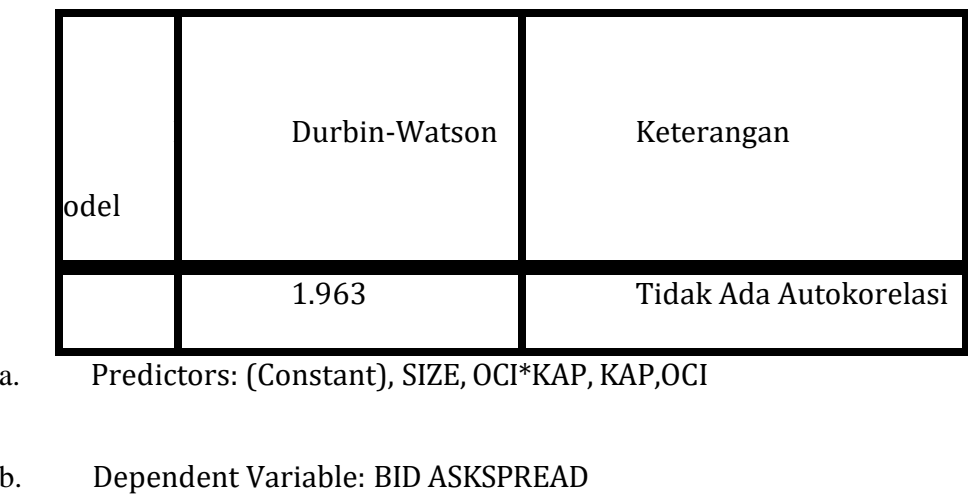

Berdasarkan hasil output Tabel 4.5 diatas diketahui nilai DW 1.963 berada pada interval 1,55 - 2,46 yang artinya tidak terjadi autokorelasi pada penelitian ini.

\section{Analisa Regresi Linear Berganda}

Pada penelitian ini pengujian hipotesis yang digunakan adalah model regresi linear berganda.Pengujian ini dilakukan untuk mengetahui pengaruh suatu variabel independen terhadap variable dependen.

Hasil regresi linear berganda yang diolah dengan SPSS adalah sebagai berikut: 
Tabel 4.6

\section{Hasil Pengolahan Regresi Linear Berganda}

\section{Coefficients ${ }^{a}$}

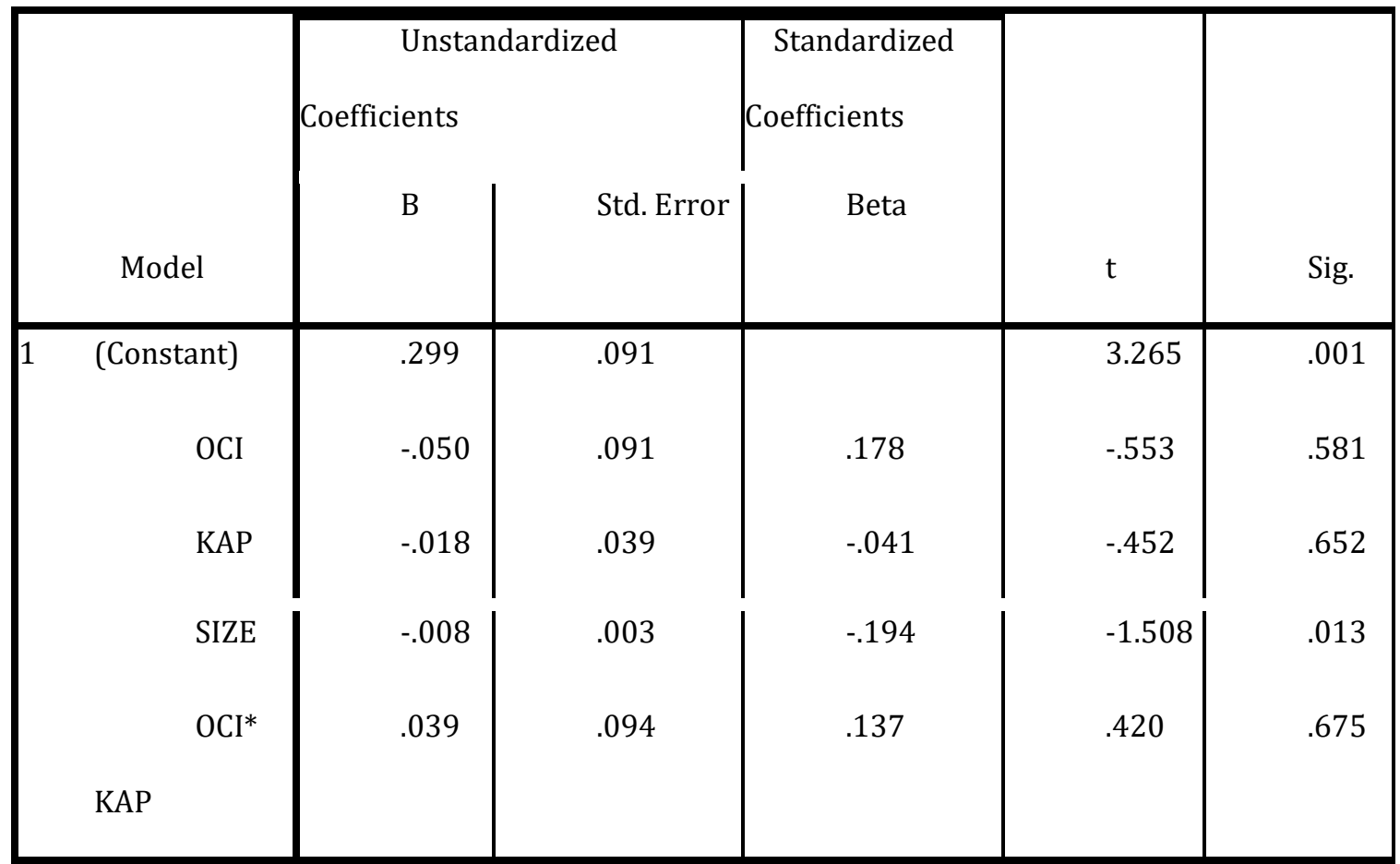

a. Dependent Variable: BID ASK SPREAD

Berdasarkan hasil pengolahan SPSS,analisisregresi linear berganda memiliki nilai constanta sebesar 0.299 , sedangkan variabel OCI memiliki nilai sebesar -0.050 , untuk variabel KAP nilainya sebesar -0.018 , Kemudian variabel SIZE nilainya sebesar -0.008 serta variabel OCI*KAPnilainya sebesar 0.039. Maka diperoleh persamaan:

\section{Model Persamaan}

bid ask spread $=0.299-0.050 \mathrm{OCI}-0.018 \mathrm{KAP}+0.039$

OCI*KAP - 0.008 SIZE

Konstanta sebesar 0.299 berarti apabila nilai pengungkapan OCI, kualitas dan OCI*KAP 
0, maka asimetri informasi perusahaan di bursa Efek Indonesia sebesar 2.131. Koefisien regresi $\beta 1$ sebesar -0.050berarti bahwa pengungkapan other comprehensive income (OCI), berpengaruh terhadap penurunan asimetri informasi sebesar 5\% dengan asumsi variabel independent lainnya konstan. Koefisien regresi $\beta 2$ adalah sebesar -0.018 . Koefisien regresi $\beta 3$ sebesar 0.039 berarti bahwa setiap kenaikan pada variabel moderator, akan berpengaruh terhadap penurunan asimetri informasi sebesar 0.039 dengan asumsi variabel lainnya konstan. Koefisien $\beta 4$ sebesar -0.018 yang berarti bahwa semakin besar ukuran perusahaan yang diukur dengan total asset, maka akan menurunkan asimetri informasi sebesar0.018 dengan asumsi variabel lainnya konstan.

\section{Koefisien Determinasi}

\section{Tabel 4.7 Koefisien Determinasi}

\section{Model Summaryb}

\begin{tabular}{|c|c|c|c|l|}
\hline Mode & $\mathrm{R}$ & $\mathrm{R}$ & Adjusted R Square & Estimate \\
\hline 1 & $.198^{\mathrm{a}}$ & .039 & .016 & .128 \\
\hline
\end{tabular}

a. Predictors: (Constant), OCI*KAP, SIZE, KAP,OCI

b. Dependent Variable: BID ASKSPREAD

Pada tabel 4.7 dapat dijelaskan nilai $\mathrm{R}$-square $\left(\mathrm{R}^{2}\right)$ sebesar 0.039 yang menunjukkan bahwa 3,9\% perubahan asimetri informasi dipengaruhinoleh variabel pengungkapan other comprehensive income (OCI), KAP dan OCI*KAP, sedangkan sisanya sebesar 96,1\% ditentukan oleh variabel lain diluar model. Sedangkan nilai Adjusted RSquare sebesar 0,016, Banyak peneliti yang menganjurkan untuk menggunakan nilai 
adjusted $\mathrm{R}^{2}$ pada saat mengevaluasi mana model regresi yang terbaik. Karena nilai pada adjusted $\mathrm{R}^{2}$ naik atau turun apabila satu variabel independent ditambahkan ke dalam model. Ghozali (2013) menemukan untuk regresi linear berganda sebaiknya menggunakan R square yang sudah disesuaikan atau tertulis Adjusted $R$ square untuk melihat koefisien determinasi, karena disesuaikan dengan jumlah variabel independent yang digunakan, dimana jika variabel independent 1 (satu) maka menggunakan $R$ squaredan jika telah melebihi 1 (satu) menggunakan adjusted $R$ square.

\section{Uji Hipotesis}

Uji F dilakukan untuk menguji apakah model regresi yang digunakan sudah fit. Dasar pengambilan keputusan dilakukan dengan melihat nilai signifikansi F pada output hasil regresi menggunakan spss dengan significance level

$0.05(\alpha=5 \%)$, dimana hipotesis diterima jika sig $\mathrm{F}<0.05$ dan ditolak jika sig $\mathrm{F}>$ 0.05. Pada penelitian ini hipotesis yang telah di rumuskan adalah:

$\mathrm{H}$ : pengungkapan other comprehensiveincome berpengaruh terhadap asimetri informasi yang dimoderasi oleh kualitas audit 
Tabel 4.8

Uji statistic 
ANOVA $^{b}$

\begin{tabular}{|l|c|c|c|c|c|}
\hline Model & Sumof & Mean & & \\
& Squares & Df & Square & F & Sig. \\
\hline Regression & .110 & 4 & .027 & 1.688 & $.003^{\mathrm{a}}$ \\
Residual & 2.699 & 166 & .016 & \\
Total & 2.809 & 170 & & & \\
\hline
\end{tabular}

a. Predictors: (Constant), OCI*KAP, SIZE,KAP, OCI

b. Dependent Variable: BID ASK SPREAD

Tabel 4.8menjelaskan bahwa hipotesis $\mathrm{F}$ atau hipotesis secara bersama-sama memiliki nilai sig $<\alpha$ yaitu0.003 $<0.05$, hal ini berarti bahwa model regresi pada penelitian ini fityang menjelaskan bahwa pengungkapan OCI, KAP, SIZE dan OCI*KAP secara simultan berpengaruh terhadap asimetri informasi.

Berdasarkan hasil analisa dengan spss maka didapat bahwa pengungkapan Other Comprehensive income berpengaruh terhadap asimetri informasi,yang dimoderasi oleh kualitas audit. Hasil uji F menunjukkan nilai sebesar 0.03.

Dari Perusahaan keuangan yang menjadi sampel pada penelitian ini, bahwa setiap perusahaan yang telah mengungkapkan other comprehensiveincome dengan melaporkan keuntungan dan kerugian dari setiap komponen-komponen other comprehensive income kedalam laporan laba rugi komprehensif disertai dengan pengungkapan tambahan pada catatan atas laporan keuangan. Adanya pengungkapan tambahan disertai dengan adanya 
pajak penghasilan yang harus dibayarkan terkait dengan komponen other comprehensive income yang diungkapkan menurunkan asimetri informasi antara agen dan prinsipal.

Perusahaan yang menjadi sampel pada penlitian ini telah diaudit oleh Kantor Akuntan Publik. Kantor Akuntan publik dapat diklasifikasikan menjadi kategori, big four dan non-big four. Lee dan Park (2013) bahwa KAP big four memiliki perhatian yang lebih tinggi terhadap litigation risk, memiliki kemampuan dalam mengurangi kesenjangan informasi, sering menghadapi inspeksi, serta memiliki kemampuan yang lebih baik dalam mengatasi keterbatasan system akuntansi karena kap big four memiliki teknologi audit yang lebih baik dan pengetahuan yang lebih baik dalam menginterpretasikan standar akuntansi dibandingkan dengan KAP non- big four. Lee dan Park (2013) juga menemukan semakin tinggi kualitas audit yang diperoleh dengan ukuran KAP sebagai proksinya, maka semakin baik dalam melakukan pemeriksaan atas kewajaran estimasi akuntansi yang digunakan oleh kliennya. Ukuran KAP yang tergolong big four lebih mampu menghasilkan informasi akuntansi yang berkualitas karena auditor KAP big four memiliki kemampuan dan keterampilan yang lebih memadai untuk melakukan proses pengauditan.

Tingkat pengaruh kualitas audit terhadap hubungan pengungkapan other comprehensive income dengan asimetri informasi yaitu sebesar $2 \%$ yang didapat dari nilai adjusted $R^{2}$ sebesar 0.016 . Rendahnya pengaruh tersebut disebabkan oleh masih banyaknya faktor atau variabel lainnya yang dapat mempengaruhi asimetri informasi.Selain itu, pengungkapan dan penyajian other comprehensive income (OCI) pada laporan laba rugi komprehensif masih sedikit dilakukan oleh perusahaan yang terdaftar di Bursa Efek 
Indonesia. Hal ini juga dapat menurunkan tingkat pengaruh other comprehensive income (OCI) terhadap asimetri informasi karena investor tidak dapat memperoleh informasi mengenai OCI pada perusahaan yang merupakan sampel yang terdaftar di BEI.

Pengungkapan OCI pada laporan keuangan menurunkan tingkat asimetri informasi antara investor dan pihak manajemen.Penelitian oleh Greenstein dan sami(1990) telah terbukti bahwa kewajiban mengungkapkan informasi akuntansi oleh SEC pada perusahaan di Amerika Serikat telah mengurangi adanya asimetri informasi dengan penurunan nilai bid ask spread.

Penelitian mengenai pengungkapan laporan keuangan dengan asimetri informasi yang telah dilakukan oleh Lang (2010) memberikan bukti bahwa pengungkapan informasi akuntansi yang lebih baik, mempengaruhi asimetri informasi yang ditunjukkan oleh penurunan rasio bidaskspread. Healy dan palepu (2010) menemukan bahwa pengungkapan informasi laporan keuangan adalah salah satu cara untuk mengurangi terjadinya asimetri informasi.

\section{DAFTAR PUSTAKA}

Akbar, Guys, Fahmi. 2015. Pengungkaapan Other Comprehensif Income (OCI), Asimetri Informasi dan Praktik Manajemen Laba.

Ujiyanto, Arief . Asimetri Informasi dan Manajemen Laba: Suatu TinjauanDalam Hubungan Keagenan.http//www.google.co.id

Barkerville 2010.Are IFRS-based and US GAAP-based Accounting Amounts Comparable.Journal of Accounting and Economic.54 pp.68.93.

De Angelo. 1981.Auditor Size and Audit Quality. Journal of Accounting And Economics. 3 
(1981) 183-199 North-Holland Publishing Company.

Ghozali, Imam. 2011. Aplikasi Analisis Multivariat dengan Program SPSS. Penerbit Erlangga. Jakarta.

Lang, Mark and Russell Lundholm. 2010, Corporate Disclosure Policy and Analyst behavior, The Accounting Review

Lee \& Park.(2013). Factors quality audit, size, leverage, earning management.Journal of accounting and manajemen.

Machfoed.1994. Pengaruh Karakteristik Perusahaan Terhadap Ukuran Perusahaan dan Manajemen Laba. Jakarta

Mardiyah, Aida Ainul. 2002. Pengaruh Asimetri Informasi dan Disclosure Terhadap Cost of Capital.Jurnal Riset Akuntansi Indonesia 5

Nichols, D. dan K. Price. 1976. The Auditor-Firm Conflict: An Analysis Using Concepts of Exchange Theory. The Accounting Review.

Pranita, Ike.2016. Pengaruh Kualitas Audit terhadap Hubungan Pengungkapan Other Comprehensive Income dengan Relevansi Nilai Informasi Akuntansi pada Perusahaan yang Terdaftar di Bursa Efek Indonesia. Universitas Andalas

Rissi, Dita maretha. 2016. Pengaruh Kualitas Audit Terhadap Hubungan Pengungkapan Other Comprehensive Income dengan Mnajemen Laba Pada Perusahaan yang Terdaftar di Bursa Efek Indonesia.Universitas Andalas 